\title{
Studies on the Utilization of Forage and the Digestion of Cellulose and Hemicellulose by Pigs
}

\author{
Tadashi Yoshimoto and Nobuhiko Matsubara* \\ School of Veterinary Medicine, Azabu University, \\ Sagamihara-shi 229 \\ ${ }^{*}$ Nichirei Shiryo K.K., Funabashi-shi 273
}

(Received June 9, 1983)

\begin{abstract}
Utilization by pigs of brassicas (Shimofusa turnip leaves and cabbage leaves), legumes (alfalfa and Ladino clover) and grasses (orchard-tall fescue mixture and Italian rye grass) and the digestibilities of cellulose and hemicellulose were studied using a total of 28 head of $76 \sim 88 \mathrm{~kg}$ pigs. 1. The dry matter of all forages except orchard-tall fescue mixture was rich in protein $(15 \sim 26 \%)$. The percentages of total digestible nutrients were higher (over 50\%) in cabbage leaves, Shimofusa turnip leaves and Ladino clover than in the other three forages. 2. The cell wall contents were high in the grass and alfalfa, and were low in Ladino clover and the brassicas. 3. The cellulose contents were higher than the hemicellulose contents in all forages. Cellulose in the brassicas and Ladino clover was easily digestible. 4. Digestibility of hemicellulose was higher than that of cellulose for all forages. 5. Shimofusa turnip leaves, cabbage leaves and Ladino clover are useful forages for the pig. Early cut alfalfa may also be useful. Crasses with high cell wall content have limited usefulness.
\end{abstract}

Jpn. J. Zootech. Sci., 54 (11): $748-754,1983$

Recently, the nutritive value of forage has been revalued and high levels of green grass, silage or hay are fed to non-herbivora ${ }^{1,2,3)}$. Since methods for the analysis of forage fiber were developed by VAN SoEST ${ }^{4,5}$, the terms acid detergent fiber (ADF) and neutral detergent fiber (NDF) have become widely used instead of crude fiber. It is also desirable to determine the contents of mono- and oligo-saccharides, fructosan and starch in nitrogen free extracts.

The dry matter of forage can be divided into the fibrous part (cell-wall constituents, i. e., cellulose, hemicellulose and lignin) and the soluble part (organic cellular constituents, i.e., sugars, soluble carbohydrates, starch, pectin, nonprotein nitrogen, proteins and lipids) to facilitate more precise evaluation of the chemical fractions of plant tissues. The ratios of cell wall constituents to organic cellular contents may range trom 40:60 in legume forages to $60: 40$ in grass forages ${ }^{6}$. While the digestibility in pigs of the cell wall fraction is limited, that of the soluble fraction is generally high $^{5}$.

Sullivan indicated a lower digestibility of hemicellulose as compared with cellulose by using ruminants? ${ }^{7}$, but KEYs reported that the digestion coefficients for hemicellulose in pigs were higher than those for cellulose ${ }^{8)}$. 


\section{Forage Utilization and Cellulose Digestion by Pigs}

The purpose of this research was to study the utilization of brassicas, legumes and grasses for the pig and to compare the digestibilities of hemicellulose and cellulose in pigs fed these forages.

\section{Experimental Procedures}

Six species from three families of forage: brassicas (Shimofusa turnip leaves and cabbage leaves), legumes (alfalfa and Ladino clover) and grasses (one to one mixture of orchard grass and tall fescue, and Italian rye grass) were used in this experiment. Shimofusa turnip leaves were harvested before bloom in April. Cabbage leaves were collected immediately after harvesting the cabbage heads in May. The alfalfa used was imported from foreign countries. Ladino clover was of the 5th cutting harvested before bloom in October. The one to one mixture of orchard grass and tall fescue was the 3rd crop harvested in July, and Italian rye grass was cut in the early heading stage in May. The experimental composition of diets of each forage and the number of pigs used in this experiment are shown in Table 1. To prepare the experimental diets, each kind of forage was mixed with either basal feed A or basal feed $\mathrm{B}$ at proportions indicated in Table 1. The meal of the mixture of orchard grass and tall fescue (orchard-tall fescue mixture) were made by the sun curing system, and other meals were made by the pneumatic drying system with hot air. The meals were ground through a $1.0 \mathrm{~mm}$ Wiley mill screen. The digestion tests were conducted using a total of 28 pigs weighing $76 \mathrm{~kg}$ to $88 \mathrm{~kg}$ (Landrace and Landrace $\times$ Hampshire). Pigs were held individually in metabolism crates, and were fed a diet of equal amounts three times each day at 09:00 hr., 13:00 hr. and 17:00 hr. by standard ration for performance test on meat production of pigs. The digestibilities

Table 1. Forages and experimental diets

\begin{tabular}{|c|c|c|c|c|}
\hline Forage ${ }^{1}$ & \multicolumn{2}{|c|}{ Experimental diet } & \multicolumn{2}{|c|}{ Number of pigs } \\
\hline Brassica & $\%$ Air & dry matter & -- & \\
\hline S.turnip leaves & S. Turnip 1. meal & $40+$ Basal feed $A^{2)}$ & 60 & 3 \\
\hline Cabbage leaves & Cabbage 1. meal & $40+$ Basal feed $A$ & 60 & 3 \\
\hline \multicolumn{5}{|l|}{ Legume } \\
\hline Alfalfa & Alfalfa meal & $50+$ Basal feed $B^{3}$ & 50 & 6 \\
\hline Ladino clover & L. clover meal & $50+$ Basal feed $B$ & 50 & 5 \\
\hline \multicolumn{5}{|l|}{ Grass } \\
\hline O.grass + t. fescue & o.g.tt.f. meal & $50+$ Basal feed B & 50 & 6 \\
\hline Italian rye grass & I. rye g. meal & $50+$ Basal feed B & 50 & 5 \\
\hline
\end{tabular}

1) S. turnip leaves $=$ Shimofusa turnip leaves. O.grass $+t$. fescue =one to one mixture of orchard grass and tall fescue. The meal of orchard grass + tall fescue mixture was made by sun curing system, and others were made by pneumatic drying system. The meals were ground through a $1.0 \mathrm{~mm}$ Wiley mill screen. 2) Basal feed A was a mixture of $60 \%$ of formula feed and $40 \%$ of wheat bran. 3) Basal feed B was a mixture of $40 \%$ of glucose, $30 \%$ of casein, $30 \%$ of tallow and traces of vitamins and minerals. 
Yoshimoto and Matsubara

Table 2. Chemical composition of forages

\begin{tabular}{|c|c|c|c|c|c|c|c|c|}
\hline \multirow{3}{*}{ Forage } & \multirow{3}{*}{ Moisture } & \multicolumn{7}{|c|}{ Dry matter } \\
\hline & & \multirow{2}{*}{$\begin{array}{l}\text { Crude } \\
\text { protein }\end{array}$} & \multirow{2}{*}{$\begin{array}{l}\text { Crude } \\
\text { fat }\end{array}$} & \multirow{2}{*}{$\begin{array}{l}\text { Mono } \cdot \text { oligo } \\
\text { saccharide }\end{array}$} & \multirow{2}{*}{$\begin{array}{l}\text { Fructosan } \\
\text { or starch }\end{array}$} & \multirow{2}{*}{$\begin{array}{l}\text { Crude } \\
\text { ash }\end{array}$} & \multicolumn{2}{|c|}{ Organic matter } \\
\hline & & & & & & & $\mathrm{OCC}$ & $\mathrm{NDF}$ \\
\hline & 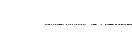 & & . & - $\%$ Dry & matter & & & \\
\hline S. turnip leaves & 11.4 & 20.2 & 3.0 & 10.0 & 1. $2^{\mathrm{a}\}}$ & 18.6 & 43.8 & 37.6 \\
\hline Cabbage leaves & 13.8 & 15.0 & 5.3 & 2.6 & $0.7^{\mathrm{a} j}$ & 20.0 & 50.1 & 29.9 \\
\hline Alfalfa & 10.7 & 19.2 & 3.5 & 5.1 & $1.1^{a)}$ & 10.5 & 41.3 & 48.2 \\
\hline Ladino clover & 8.6 & 26.3 & 3.6 & 2.2 & 0 & 13.2 & 55.1 & 31.7 \\
\hline O.grass + t. fescue & 10. 7 & 12.4 & 2.9 & 2.5 & $0.6^{\mathrm{b})}$ & 12.8 & 18.3 & 68.9 \\
\hline Italian rye grass & 12.3 & 18.2 & 2.7 & 1.3 & $0.9^{b)}$ & 12.3 & 24.6 & 63.1 \\
\hline
\end{tabular}

a) $=$ Starch, b) $=$ Fructosan. $\quad O C C=$ Organic cellular contents. NDF $=$ Neutral detergent fiber $=$ cell wall.

were examined by the total collection method during a 5-day collection period following 4-day preliminary period.

Chemical compositions of the forages were analysed by conventional methods ${ }^{9}$. Cell wall constituents and cell contents were precisely analyzed by an improved method $^{10,11)}$ of the detergent procedures of VAN SoEsT ${ }^{5)}$. The cellulose contents were determined by subtracting lignin contents from the $\mathrm{ADF}$ value and hemicellulose contents were determined by subtracting the ADF value from the NDF value. Monosaccharide, oligo-saccharide and fructosan were determined by anthrone colorimetry methods, and starch content was determined by the glucoseoxidase method ${ }^{12}$. Digestibility of basal feed $A$ had been measured before giving these experimental diets, and basal feed $\mathrm{B}$ was considered to be digested perfectly.

\section{Results}

Chemical compositions of the forages are presented in Table 2. All forages except the orchard-tall fescue mixture showed high percentages $(15 \sim 26 \%)$ of protein content in their dry matter. The mono- and oligo-saccharide content of Shimofusa turnip leaves was as high as $10 \%$. As can be calculated from the figures shown in Table 2 , the ratios of organic cellular contents to the total organic matter were 0.54 for Shimofusa turnip leaves, 0.63 for cabbage leaves and 0.63 for Ladino clover. The ratio for alfalfa was comparatively low (0.46). Both of the grasses, orchard-tall fescue mixture and Italian rye grass, contained large amounts of cell wall (NDF) : $79 \%$ and $72 \%$ respectively.

The digestibilities of forages are as presented in Table 3. The digestibility of organic matter of the brassica family was higher than the other two families. Alfalfa and Italian rye grass showed the same digestibility, but that of orchard-tall fescue mixture was low. Digestibility of protein was similar to that of organic matter. Precise determination of fat digestibility for both legumes and grasses was not possible because of the presence of large amount of tallow that was mixed in these experimental diets. Organic cellular contents of the brassica leaves and Ladino clover were 
Forage Utilization and Cellulose Digestion by Pigs

Table 3. Digestibility of forages in pigs

\begin{tabular}{|c|c|c|c|c|c|}
\hline \multirow{2}{*}{ Forage } & \multirow{2}{*}{$\begin{array}{l}\text { Organic } \\
\text { matter }\end{array}$} & \multirow{2}{*}{ Crude prot. } & \multirow{2}{*}{ Crude fat } & \multicolumn{2}{|c|}{ Organic matter } \\
\hline & & & & OCC & $\mathrm{NDF}(\mathrm{CW})$ \\
\hline & & & $\%$ & & $\ldots$ \\
\hline S. turnip leaves & $20.1 \pm 4.4$ & $79.8 \pm 4.1$ & $66.7 \pm 5.9$ & $76.5 \pm 3.6$ & $65.5 \pm 5.1$ \\
\hline Cabbage leaves & $74.5 \pm 5.3$ & $68.7 \pm 3.7$ & $67.7 \pm 3.1$ & $67.6 \pm 4.9$ & $86.2 \pm 9.6$ \\
\hline Alfalfa & $41.6 \pm 3.2$ & $57.8 \pm 2.6$ & 0 & $46.1 \pm 3.6$ & $37.9 \pm 4.2$ \\
\hline Ladino clover & $59.1 \pm 1.3$ & $66.8 \pm 1.7$ & 0 & $61.4 \pm 1.8$ & $56.6 \pm 0.5$ \\
\hline O. grass + t. fescue & $27.5 \pm 0.8$ & $42.7 \pm 2.3$ & $4.9 \pm 5.7$ & $12.1 \pm 0.9$ & $31.6 \pm 1.0$ \\
\hline Italian rye grass & $42.3 \pm 2.3$ & $63.4 \pm 1.6$ & $8.9 \pm 7.7$ & $36.9 \pm 1.6$ & $44.3 \pm 3.1$ \\
\hline
\end{tabular}

Table 4. Digestible nutrients of forages for pigs

\begin{tabular}{|c|c|c|c|c|c|c|c|}
\hline \multirow{2}{*}{ Forage } & \multirow{2}{*}{$\begin{array}{l}\text { Organic } \\
\text { matter }\end{array}$} & \multirow{2}{*}{$\begin{array}{l}\text { Crude } \\
\text { protein }\end{array}$} & \multirow{2}{*}{$\begin{array}{l}\text { Crude } \\
\text { fat }\end{array}$} & \multirow{2}{*}{$\begin{array}{c}\text { Soluble } \\
\text { carbohydrate }\end{array}$} & \multicolumn{2}{|c|}{ Organic matter } & \multirow{2}{*}{ TDN* } \\
\hline & & & & & $\overline{\mathrm{OCC}}$ & $\overline{\mathrm{NDF}}(\mathrm{CW})$ & \\
\hline & & & 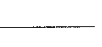 & $\%$ Dry matter & - & & $\ldots$ \\
\hline S.turnip leaves & 57.1 & 16.1 & 2.0 & 11.2 & 33.5 & 24.6 & 59.6 \\
\hline Cabbage leaves & 59.6 & 10.3 & 3.6 & 3.3 & 33.9 & 25.8 & 64.1 \\
\hline Alfalfa & 37.2 & 11.1 & 0 & 6.2 & 19.0 & 18.3 & 37.2 \\
\hline Ladino clover & 51.3 & 17.6 & 0 & 2.2 & 33.8 & 17.9 & 51.3 \\
\hline O. grass + t. fescue & 24.0 & 5.3 & 0.1 & 3.1 & 2.2 & 21.8 & 24.1 \\
\hline Italian rye grass & 37.1 & 11.5 & 0.2 & 2.2 & 9.1 & 28.0 & 37.4 \\
\hline
\end{tabular}

$*$ TDN = total digestible nutrients.

Table 5. Structural carbohydrate contents in forages

\begin{tabular}{lcccc}
\hline \multicolumn{1}{c}{ Forage } & NDF $(\mathrm{CW})$ & Cellulose & Hemicellulose & Lignin \\
& & & $\%$ & Dry \\
& 37.6 & 26.8 & 4.7 & 6.1 \\
S. turnip leaves & 29.9 & 14.4 & 7.8 & 7.7 \\
Cabbage leaves & 48.2 & 24.4 & 14.1 & 9.7 \\
Alfalfa & 31.7 & 14.1 & 11.3 & 6.3 \\
Ladino clover & 68.9 & 32.2 & 30.1 & 6.6 \\
O. grass +t. fescue & 63.1 & 33.5 & 24.4 & 5.2 \\
Italian rye grass & 6 & & & \\
\hline
\end{tabular}

more digestible than those of alfalfa and Italian rye grass. The orchard-tall fescue mixture was the least digestible.

Digestible nutrients of forages were shown in Table 4. High digestible crude protein (DCP) contents were observed for Shimofusa turnip leaves (16.1\%) and Ladino clover $(17.6 \%)$. The DCP contents of alfalfa, cabbage leaves and Italian rye grass were lower $(11.1 \%, 10.3 \%$ and $11.5 \%$ respectively). The value for orchardtall fescue mixture was approximately half of that for Italian rye grass, which belongs to the same family.

The total digestible nutrients (TDN) was most abundant in cabbage leaves $(64.1 \%)$, 
Table 6. Digestibility of cellulose and hemicellulose in forages in pigs

\begin{tabular}{lcc}
\hline Forage & Cellulose & Hemicellulose \\
\cline { 2 - 3 } & & \\
S.turnip leaves & $71.4 \pm 0.2$ & $79.3 \pm 26.7$ \\
Cabbage leaves & $84.9 \pm 5.0$ & $94.3 \pm 9.9$ \\
Alfalfa & $43.5 \pm 3.7$ & $55.7 \pm 5.7^{* *}$ \\
Ladino clover & $60.8 \pm 1.8$ & $69.5 \pm 3.2^{* *}$ \\
O. grass $+\mathrm{t}$ fescue & $29.4 \pm 2.0$ & $50.5 \pm 0.4^{* *}$ \\
Italian rye grass & $41.6 \pm 3.1$ & $50.1 \pm 3.9 * *$ \\
\hline$* * P<0.01$ & &
\end{tabular}

followed by Shimofusa turnip leaves and Ladino clover (over 50\%). Alfalfa and Italian rye grass showed the low value of $37 \%$. The lowest value was obtained with orchard-tall fescue mixture $(24 \%)$.

The results of analysis of structural carbohydrate contents are summarized in Table 5. Cell wall content was high in the grasses and alfalfa, but low in Ladino clover and brassica forages. The cellulose contents were higher than the hemicellulose contents in all forages. Hemicellulose content was lowest in the brassicas (less than $8 \%$ ), moderate in the legumes $(11 \sim 14 \%$ ) and highest in the grasses. Among all forages, alfalfa showed the highest lignin content.

Table 6 shows digestibilities of cellulose and hemicellulose in forages. The cellulose of brassica meals was most easily digestible, and that of Ladino clover was the next. Digestibility of cellulose in alfalfa and Italian rye grass was comparatively low, and that of orchard-tall fescue mixture was the lowest. Digestibility of hemicellulose in brassica forages and Ladino clover was comparatively high $(70 \sim 94 \%)$ but that of the other forages was only slightly over $50 \%$. Hemicellulose was more digestible than cellulose for all forages.

\section{Discussion}

The literature ${ }^{1,2,13.14)}$ on utilization and digestion of forages by the pig states that legumes are efficiently digested by pigs ${ }^{15}$. In particular, high quality alfalfa meal can be utilized similarly by the pig as by ruminants ${ }^{3,8}$. In this study, we compared the chemical compositions and the digestibilities of the constituents of forages: two species each of three families, i. e., brassica, legume and grass. The results indicated that the orchard-tall fescue mixture is not a useful forage for the pig because of its low digestible crude protein (DCP) content, low total digestible nutrients (TDN) content and high cell wall content.

The alfalfa had an unexpectedly low TDN value with the highest lignin content among all the forages, even though the DCP content was reasonable. Judging from the report by MIAKI ${ }^{16)}$ that DCP and TDN values of alfalfa rapidly decline while contents of crude fiber and lignin increase after the blooming stage, the alfalfa sample 
used in the present study was probably of rather late stage. It has been reported by Sмrтн et $a{ }^{17}{ }^{17)}$ that the pig could digest the cell walls of immature rye while digestibility of cell walls of mature timothy was very poor. The Italian rye grass used in our experiments had been harvested in May, when the grass was in the early heading stage. The high crude protein content was comparable to that of alfalfa and the digestibilities of organic matter, crude protein and cell walls of this grass were higher than those of alfalfa. This indicates that early cut Italian rye grass could be a useful meal for the pig.

The data presented in Table 5 and 6 show that there is a general tendency that the digestibility of cellulose is better when their content in the diet (except Shimofusa turnip leaves) is lower, although it is probable that the digestibility of cellulose is influenced by the character of cellulose in forages.

This is in agreement with the report by FARRELL et $a{ }^{18}{ }^{18}$ ) who found that cellulose was more digestible when the diet contained $8 \%$, rather than $26 \%$, of cellulose.

Digestion of fibrous materials depends on digestibilities of cellulose and hemicellulose. According to Sullivan ${ }^{7}$, in ruminants, namely sheep and calves, cellulose is more easily digested than hemicellulose when examined with forages including alfalfa, legume silage and several species of grass. In contrast, KEYs, et al. ${ }^{19)}$, who conducted digestion tests for cellulose and hemicellulose of orchard grass hay with pigs and rats, reported that hemicellulose was more digestible than cellulose in these non-ruminant animals. The results of our experiments showing that digestibility in pigs of hemicellulose contained in all of the six species of forage in higher than that of cellulose, further support the report by KEYS.

Using ruminants fed Italian rye grass, timothy and rye, ABE and HoRII ${ }^{20}$ observed considerably strong negative correlations between the lignin content and the digestibilities of neutral detergent fiber and of acid detergent fiber $(r=0.994,0.999$, respectively, $P<0.01$ ). However, with the pig, we found only weak correlations $(r=0.244$, 0.187 ). It is assumed that some factors other than lignin content affect digestion of cell walls by the pig.

In conclusion, Shimofusa turnip leaves, cabbage leaves and Ladino clover are well digestible and useful forages for the pig. They should serve as a useful diet. Hemicellulose is more digestible than cellulose in pigs.

The authors wish to thank Professor I. Ishibashi and Mr. S. Kagabu, Yamaguchi University, for supporting this study and providing every facility for it.

\section{References}

1) Axelsson, J. and S. Eriksson, J. Anim. Sci, 12: 881-891. 1953.

2) Becker, D. E., L. J. Hanson, A. H. Jensen, S. W. Terrill and H. W. Norton, J. Anim. Sci., 15: 820829.1956.

3) Yоsнiмото, T., The Transactions of Faculty of Horticulture, Chiba University, 11: 1-105. 1974.

4) Van Soest, P. J., J. Anim. Sci., 23: 838-845. 1964.

5) Van Sozst, P. J., J. Assoc. Off. Anal. Chem., 19: 546-551. 1966. 
6) Keys, J. E. JR., Proc. Maryland Nutr. Conf. Feed Manufacturers, 77-82. 1975.

7) Sullivan, J. T., J. Anim. Sci., 25: 83-86. 1966.

8) Keys, J. E. Jr., P. J. Van Soest and E. P. Young, J. Anim. Sci,, 29: 11-15. 1969.

9) Morimoto, H., Döbutsu Eiyo Shikenhō. 1 st ed. 280-297. Yokendo. Tokyo. 1971. (in Japanese)

10) Horit, S. and A. Abe, Bull. Nat. Inst. Anim. Ind., 25: 63-68. 1972. (in Japanese)

11) HoriI, S. and A. AвE, Bull. Nat. Inst. Anim. Ind., 23: 83-87. 1970. (in Japanese)

12) Aвe, A. and S. Horil, Bull. Nat. Inst. Anim. Ind., 30: 27-32. 1976. (in Japanese)

13) Keys, J. E. Jr. and J. V. Debarthe, J. Anim. Sci., 39: 57-62. 1974.

14) Keys, J, E. Jr. and J. V. Debarthe, J. Anim. Sci., 39: 53-56. 1974.

15) Ishikawa, S., Jpn. J. Zootech. Sci., 37: 317-327. 1966. (in Japanese)

16) Miaki, T., Jpn. J. Zootech. Sci., 38: 96-102. 1967. (in Japanese)

17) Smith, L. W., H. K. Goerinc, D. R. Waldo and C. H. Gordon, J. Dairy Sci., 54: 71-76. 1970.

18) Farrel L, D. J. and K. A. Johnson, Anim. Prod., 14:209-217. 1970.

19) Keys, J. E. Jr., P. J. Van Soest and E. P. Younc, J. Anim. Sci., 31: 1172-1177. 1970.

20) $\mathrm{ABE}, \mathrm{A}$. and S. Horil, Bull. Nat. Inst. Anim. Ind., 25: 69-74. 1972. (in Japanese)

\section{豚における牧草およびそ菜茎葉の利用性と セルロース,ヘミセルロースの消化性}

\section{吉本 正・松原延彦*}

麻们大学獣医学部，相模原计 229

*ニチレイ飼料(侏)，船橋杖 273

アブシナ科作物であるシモフサカブ葉とキャベッ外 葉，マィ科作物であるてルフォルファとラジノタロー八 一、イネ科作物であるオーチャードグラス・トールフェ スタ混合草とイタリアンライダラスについて，豚に拈け る飼料としての利用性を検討し，特にそれらの作物につ いてセルロースとへミセルロースの消化性を比較した.

各作物は収綮後, 乾燥し、ミ一ル状にして供試した。 消化試験は延 28 頭の豚（体重：76〜88 kg）を用い，全 ふえ採取法によって行なった。細胞壁と紐胞内容物の分 析はVAN SOEST によるデタージェント処理の改良法に よって分析した：その結果は次のようであった。

1. 乾物中の粗蛋白質含量はオーチャードグラス・ト ールフェスク混合草以外は15〜26\%と高い値を示した.

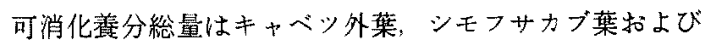
ラジノクローバーにおいて比较的高く，50\%以上を示し t.

2. 細胞壁含量はイネ科とアルファルファが高く、 シノタローバーとアブラナ科は低かった。

3. 七ルロース含量はすべての作物に拈いてへミ゙ル ロースよりも多かった.

4. フブラナ科とラジノクローバーのセルロースは消 化しやすかった。

5. 一ミセルロースはすべての作物に和いてセルロー スより高い消化率を示した。

6. 以上の結果から，アブラナ科作物の葉部，ラジ， クローバー拉よび若いステージのアルファルファは淢に とって消化しやまく，有益な作物であるが，イネ科作物 および成魰したアルファルファは細胞壁含量が高く，豚 においてて利用性が低いと推論された。

日畜会報，54(11)：748-754，1983 